\title{
P.U.V.A. - PHOTOCHEMOTHERAPY OF PSORIASIS WITH ORAL 8 - METHOXYPSORALEN AND LONG WAVE ULTRA VIOLET RADIATION
}

\author{
ELIZABETH S. McMULLAN, M.C.S.P.*
}

\section{SUMMARY}

The incidence, aetiology and clinical features of psoriasis are reviewed. The author discusses P.U.V.A., a treatment which combines the use of 8-MOP and long wave ultra violet radiation. Some encouraging results have been noted in a one-year trial at the Royal Victoria Hospital, Belfast.

Approximately $15 \%$ of the patients seen at Dermatology clinics are psoriatics; hence it is a relatively common chronic skin disease. Its incidence in different countries is variable:

Northern Ireland

United Kingdom

Denmark ...

$2-3 \%$ population

$1-2 \%$ population

$0,2-2 \%$ population

South Africa ... $\ldots, \ldots, \ldots, 0,2-1 \%$ population

(all social groups)

There is particularly low incidence in the Japanese and Negro races (Rook et al., 1968).

Although the aetiology is unkriown, heredity mayplay some part. In some patients the onset is precipitated by stress such as pregnancy, emotional strain, trauma, or infection e.g. streptococcal throat infection in children.

\section{CLINICAL FEATURES}

The typical lesion is a red patch of varying size covered with a thick layer of scales. These can be scraped of and have a characteristic silvery sheen.

Further scraping causes bleeding, but there is no serum exudate. The lesions are most often present on the extensor surfaces but almost the whole body can be covered. The scalp is a common site and there may be hyperkeratotic areas on the palms and soles. "If the nails become affected, they become thickened, pitted and striated. The condition usually persists for life with remissions and acute exacerbations.

Psoriatic arthropathy is seen in all age groups but particularly the middle aged and elderly. In association with skin lesions there is a destructive polyarthritis, usually involving the hands and feet, and characteristically affecting the distal interphalangeal joints. Sacroiliitis may also be a feature and although the joint involvement may resemble rheumatoid arthritis, the rheumatoid factor is not present in the blood.

\section{P.U.V.A.}

The term P.U.V.A. has been coined to define a form of treatment which combines the use of psoralen as a photo-sensitizing agent and irradiation of the skin with ultra violet light. The ultra violet radiation used in this treatment differs from that used in conventional physiotherapy in that the middle and short waves are omitted:

U.V.A. (long wave) $320-400 \mathrm{~nm}\left(3200 \mathrm{~A}^{\circ}-4000 \mathrm{~A}^{\circ}\right.$ )

U.V.B. (midwave) $290-320 \mathrm{~nm}\left(2900 \mathrm{~A}^{\circ}-3200 \mathrm{~A}^{\circ}\right.$ )

U.V.C. (shortwave) $100-290 \mathrm{~nm}\left(1000 \mathrm{~A}^{\circ}-2900 \mathrm{~A}^{\circ}\right)$

The $A$ band of the spectrum is isolated using a specially designed machine.

* Physiotherapist, King Edward VIII Hospital, Durban. Formerly Senior Physiotherapist, P.U.V.A. Unit, Royal Victoria Hospital, Belfast.

Received 12 December 1980.

\section{OPSOMMING}

Die insidensie, etiologie en kliniese voorkoms van psoriase word hersien. Die skrywer bespreek P.U.V.A., ' $n$ behandeling wat die gebruik van 8-MOP en lang golf ultravioletbestraling kombineer. Bemoedigende resultate in ' $n$ ondersoek van een jaar aan die Royal Victoria Hospital, Belfast, word aangeteken.

\section{Exposure dose}

This is measured in Joules per square centimetre $\left(\mathrm{m}^{2}\right)$ and is the product of the radiation of the machin and the time the patient is exposed for.

Radiation $\mathrm{x}$ exposure time $=$ exposure dose.

$$
\mathrm{W} / \mathrm{cm}^{2} \times \text { seconds } \quad=\text { Joules } / \mathrm{cm}^{2}
$$

$$
\begin{aligned}
\frac{\mathrm{MW} / \mathrm{cm}^{2}}{1000} \times \frac{\operatorname{mins} \times 60}{1} & =\frac{\text { Joules } / \mathrm{cm}^{2}}{1} \\
\text { or Time in minues } & =\frac{\mathrm{J} / \mathrm{cm}^{2}}{\mathrm{MW} / \mathrm{cm}^{2}} \times 16,6
\end{aligned}
$$

For ready reference a slide rule made by Walder. mann has been designed which cuts down much calculation time.

\section{Apparatus}

The apparatus used in this study was the German manufactured Waldermann P.U.V.A. 6000 , for total body irradiation, and a smaller version, the P.U.V.A. 200 for individual areas. These machines can be used either separately or in conjunction with each other depending on the area of the body to be treated. Waldermann has introduced other models which are constantly being modified.

\section{8-METHOXYPSORALEN (8-MOP)}

8-MOP is one member of a group of structurally related, heterocyclic, photoactive compounds called psoralens which are derived from furocoumarins. The are naturally occurring compounds which can bi extracted from the Ami Majus (a weed which grows in the Nile Valley), parsley, parsnip, celery, lime, cloves and figs. It may be applied topically or administered orally.

Over ninety per cent of orally administered 8-MOP is absorbed from the gastrointestinal tract and is distributed to the various organs including the skin. The maximum concentration is found in the blood two to three hours after ingestion and this corresponds with the time of maximum photosensitivity of the skin. Over ninety per cent of the drug dose is excreted in the urine within twelve hours and the remainder within the next twelve hours. There is no accumulation of psoralen in the body with repeated daily consumption providing the patient has normal renal function.

8-MOP is dispensed in $10 \mathrm{mg}$ tablets. The oral dose is given exactly two hours before treatment with a light snack and is based on body weight as follows:

$$
\begin{array}{r}
\text { less than } 50 \mathrm{~kg}-20 \mathrm{mg} \\
50-60 \mathrm{~kg}-30 \mathrm{mg} \\
65-80 \mathrm{~kg}-40 \mathrm{mg}
\end{array}
$$$$
80+\mathrm{kg}-50 \mathrm{mg}
$$

In this study the $50 \mathrm{mg}$ dose was not exceeded. 


\section{THE COMBINATION OF 8-MOP AND U.V.A.}

U.V.A. and 8-MOP acting individually on the skin are ineffective, but in combination they have the effect of inhibiting D.N.A. synthesis and thus cell division.

\section{THE P.U.V.A. UNIT}

The Royal Victoria Hospital Unit was opened in August 1977 in the Department of Physical Medicine, which is in close proximity to the Department of Dermatology. Close co-ordination has always been maintained with the staff in the Department of Dermatology. The Unit runs on a 9 a.m.-5 p.m. basis with one Senior Physiotherapist on duty in the morning when the Dermatology Clinics are running. New patients and those presenting problems can be seen at this time. The afternoon clinic for maintenance patients is run by a Basic Grade Physiotherapist who rotates on a six monthly rota. This system appears to work satisfactorily and permits training of physiotherapy staff. Patients are assessed initially for P.U.V.A. suitability by a Dermaologist. This includes photographs of the skin lesions, a cill optical examination, X-rays of joints if psoriatic arthropathy is clinically present, ECG and full blood andlysis. (This is particularly important in those patients currently on a course of cytotoxic drugs, e.g. methotrexate).

Patients are then asked to discontinue all forms of treatment for psoriasis and to apply only bland aqueous cream or emulsifying ointment provided by the Department. Only those patients on methotrexate therapy are allowed to continue their medication, the dose being gradually reduced as P.U.V.A. is increased.

In the Physiotherapy Department the assessment includes the patient's family history, occupation, skin type, joint involvement, present drug regime along with a stenciled diagram of the lesions at the time of starting treatment. Suitable patients are asked to purchase a pair of dark sunglasses which are tested by a spectrophotometer (made possible by the Department of Biochemistry and Haematology) to ensure that they absorb a minimum of $370 \mathrm{~nm}$. $\left(3700 \mathrm{~A}^{\circ}\right)$.

\section{FIRST ATTENDANCE}

This consists of Test Dosing the patient in the normal way using the anterior aspect of the forearm. Exposures of $0,5,1,2,3$ and 4 Joules $/ \mathrm{cm}^{2}$ are used.

The onset of erythema is from ten to thirty hours after exposure, peaking between forty-eight and seventywo hours. If the 8-MOP is not taken, there will be no tythema. The U.V.A. dose producing a minimal erythema is selected at 72 hours and used as a starting dose. Doses are kept to an absolute minimum, maintained for two consecutive treatments and then increased by $0,5 \mathrm{~J} / \mathrm{cm}^{2}$, providing the skin does not show an obvious erythema. A set of rules is handed to each patient (Appendix I).

\section{ATTENDANCE}

Patients attend for treatment three times weekly until tiney are clear. They are then seen by a Dermatologist and put onto maintenance therapy, initially attending twice weekly with gradual reduction in attendance, pro- vided they remain clear. The majority can be maintained on one or two treatments per month. Accurate record is kept of each patient's attendance including the dose given, machine intensity, 8-MOP ingestion time, treatment time, skin condition and side effects. (Appendix II).

\section{SIDE-TFEECTS}

In the trial patients complained of pruritus in the early stages of treatment, but this gradually diminished as treatment continued, and symptomatic relief was obtained with antihistamines. A number of patients complained of temporary nausea, headaches and sweating following 8-MOP ingestion. Two patients initially developed herpes simplex, but this was further prevented by screening the lips before radiation.

\section{REPORT OF A TRIAL OVER ONE YEAR AT THE ROYAL VICTORIA HOSPITAL}

Forty five patients with severe and resistant psoriasis were treated with P.U.V.A, therapy at the Royal Victoria Hospital for a period of one year. They were selected for the trial under four groups:

Group $A$ Patients unresponsive to conventional tar and dithranol therapy.

Group $B$ Patients who had previously received large amounts of topically applied steroids.

Group $C$ Patients receiving methotrexate. It was hoped to be able to reduce and finally stop the methotrexate as the P.U.V.A. took over.

Group $D$ Psoriasis confined to the palms of the hands and soles of the feet.

\section{Results}

One hundred per cent clearing of plaques was achieved in 43 of the 45 patients treated $(95,5 \%)$ and the other two were materially improved. What was significant here was the low exposure dose which was necessary to achieve these results. Previously recorded results by Melski et al. (1977) showed the average to be $14,3 \mathrm{~J} / \mathrm{cm}^{2}$. This study showed a total average of 3,5 $\mathrm{J} / \mathrm{cm}^{2}$.

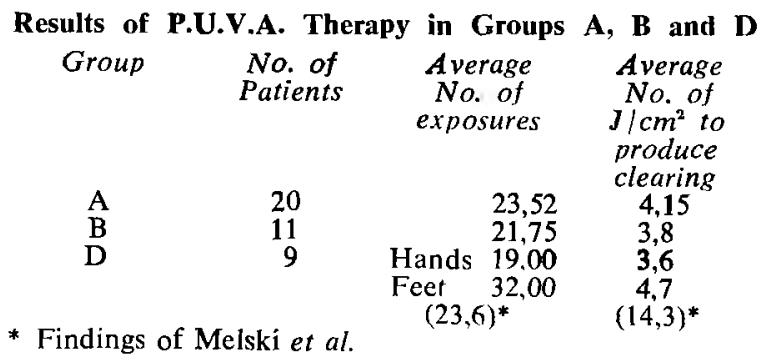

\section{Group C}

The results of this group are recorded separately. These 5 patients had previously been treated with methotrexate.

$\begin{array}{ccc} & \text { Years } & \text { Time } \\ \text { Pafiected } & \text { Treated } \\ \text { No. } & \text { By } & \text { With } \\ 1 & \text { Psoriasis } & \text { Methotrexate } \\ 2 & \frac{3}{3} & 4 \text { weeks } \\ 3 & 21 & 2 \text { yrs. } \\ 4 & 22 & 1 \frac{1}{2} \text { yrs. } \\ 5 & 30 & 1 \frac{1}{2} \text { yrs. } \\ & 23 & 2\end{array}$




\section{CONCLUSION}

Forty-five patients with Psoriasis were treated with P.U.V.A. over a period of one year. Forty-four patients obtained a response but it was necessary to continue - maintenance treatment to prevent a relapse. In two of the patients treatment at two monthly intervals was found satisfactory.

The trial was terminated in September 1978 and until May 1980 the majority of the patients remained in remission, provided they continued with regular maintenance treatment. In some patients is was necessary to continue with treatment every two weeks.

The improvement was of such a striking nature that most previously severely affected patients were willing to attend for regular treatment on a long term basis. Whether or not that is a viable proposition remains to be seen.

\section{ACKNOWLEDGEMENT}

I wish to thank Miss E. Thompson, Superintendent Physiotherapist, Miss M. Patterson and the Staff of the Department of Physical Medicine, Dr. D. Burrows, Dr. J. M. Beare, Or. Hiliary Lavery and other members of the Staff of the Department of Dermatology; also Dr. Vella Briffa and the Staff of the P.U.V.A. Unit at St. John's Hospital for Diseases of the Skin for their advice in the setting up of the P.U.V.A. Unit in the Royal Victoria Hospital, Belfast.

\section{APPENDIX I}

The following set of rules is handed to each patient:

1. Remember to take tablets two hours before treatment, with a small snack. Do not ingest tablets on an empty stomach.

2. Wear sunglasses immediately after ingestion of tablets and for the following twenty-four hours.

3. When outside or under strip lighting wear long sleeves and gloves and cover head with a scarf or hat for eight hours after ingestion of tablets.

4. Do not sunbathe for three days after ingestion of tablets.

5. Patients must be punctual for appointments. If you cannot attend then ring the P.U.V.A. Unit and arrange for a change of appointment.

6. Do not use any other creams or tablets other than those prescribed and approved by the Dermatology Department. Pure Aspirin may be taken for headaches.

7. Do not drink alcohol after ingestion of tablets for 24 hours.

8. Avoid eating shellfish, strawberries, large quantities of cream or citrus fruits for three days after treatment.

9. Do not eat more than one egg a day.

Please obey these "rules" in order to ensure that your treatment is as successful as possible.

\section{APPENDIX II}

Name: John Brown. Date

Treatment No. ...... No.

Any itching after last treatment?

Any nausea after taking 8-MOP tablets?

Any headaches?

Any perspiration?

Are your eyes sore?

Is you skin sore?

Specify site:

Erythema

Response: Faint pink/ marked red/red + oede$\mathrm{ma} / \mathrm{red}+$ oedema + blisters

Response to therapy

1. Worse 2. No change 3. Improvement.

4. Slightly less scale/or erythema

5. Less scale, less erythema, partial flattening 6 . Plaques flattened, except borders, 7. All plaques flattened but pigmented.

8. Clear.

Time under lamps

1. Pleasant 2. Bearable

3. Too long 4. Strenuously long.

8-MOP dose

UVA dose

UVA intensity

Time swallowed

Time given

Exposure time

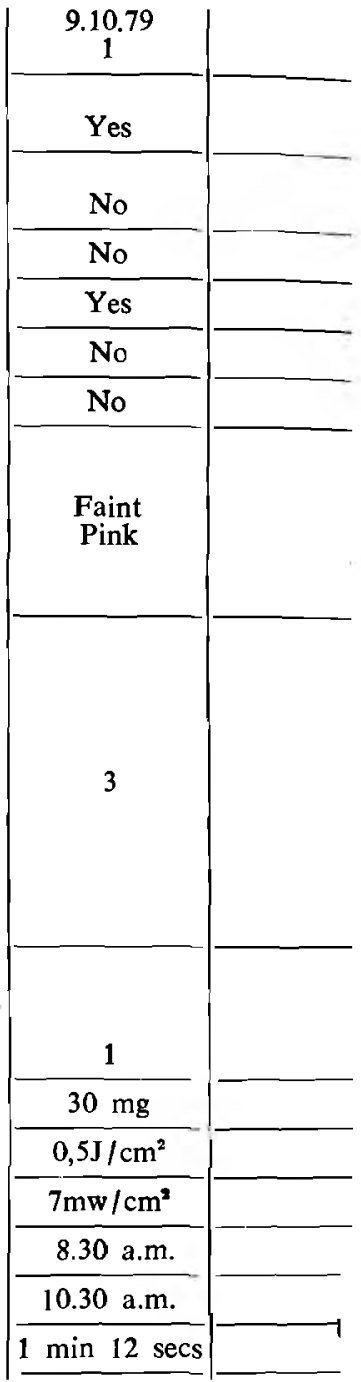

Comments:

\section{EReferences}

Melski, J. W., Tannenbaum, L., Black, H. L. and 28 participating investigators (1977). Oral methoxypsoralen photochemotherapy for the treatment of psoriasis: a co-operative clinical trial. J. of Investigative Dermatology, 68, 9.

Rock, Wilkinson and Ebling (1968). Textbook of dermatology. 2nd Ed. Blackwell. 